\section{PENERAPAN PHYSICAL DISTANCING}

DAN STRATEGI PEMASARAN USAHA PEDAGANG

PADA MASA PANDEMI COVID-19

COVID-19 (Coronavirus Disease 2019) merupakan sebab dari terjadinya penurunan pada berbagai sektor di seluruh dunia termasuk Indonesia, sektor ekonomi salah satunya khususnya pada bidang Usaha Kecil Menegah (UKM) merupakan sektor bisnis yang berperan penting dalam mendorong percepatan pertumbuhan ekonomi. Menyikapi pandemi Covid-19 ini maka berbagai kebijakan mulai dimunculkan untuk memutus penyebaran Covid-19. Mulai dari penerapan work from home, social distancing dan physical distancing, sampai diberlakukan Pembatasan Sosial Berskala Besar (PSBB).

Kebijakan-kebijakan tersebut sedikit banyak berpengaruh pada kegiatan bisnis dengan terjadinya penurunan jumlah pelanggan dan penuruanan omset pada beberapa pedagang. Penerapan jaga jarak atau physical distancing di pasar juga menjadi perhatian khusus sebab pasar merupakan interaksi antara pedagang dan penjual yang memungkinkan terjadinya kontak fisik, hal tersebut karena ruang pasar yang sempit, penuh dengan pedagang dan barang yang diperdagangankan.

Akibat dari kondisi tersebut maka metode pemasaran pada saat pandemi Covid-19 diimbangi dengan berjualan secara online, sebab untuk melaksanakan pemasaran online secara keseluruhan tidak memungkinkan karena beberapa faktor. Faktor kebiasaan seperti pada kondisi normal dimana penjualan dilaksanakan secara konvensional dengan pertemuan langsung anatara penjual dan pembeli sebagaimana layaknya pasar tradisional di seluruh Indonesia. Perihal inilah yang akan dibahas penulis dalam kajian pada buku ini.

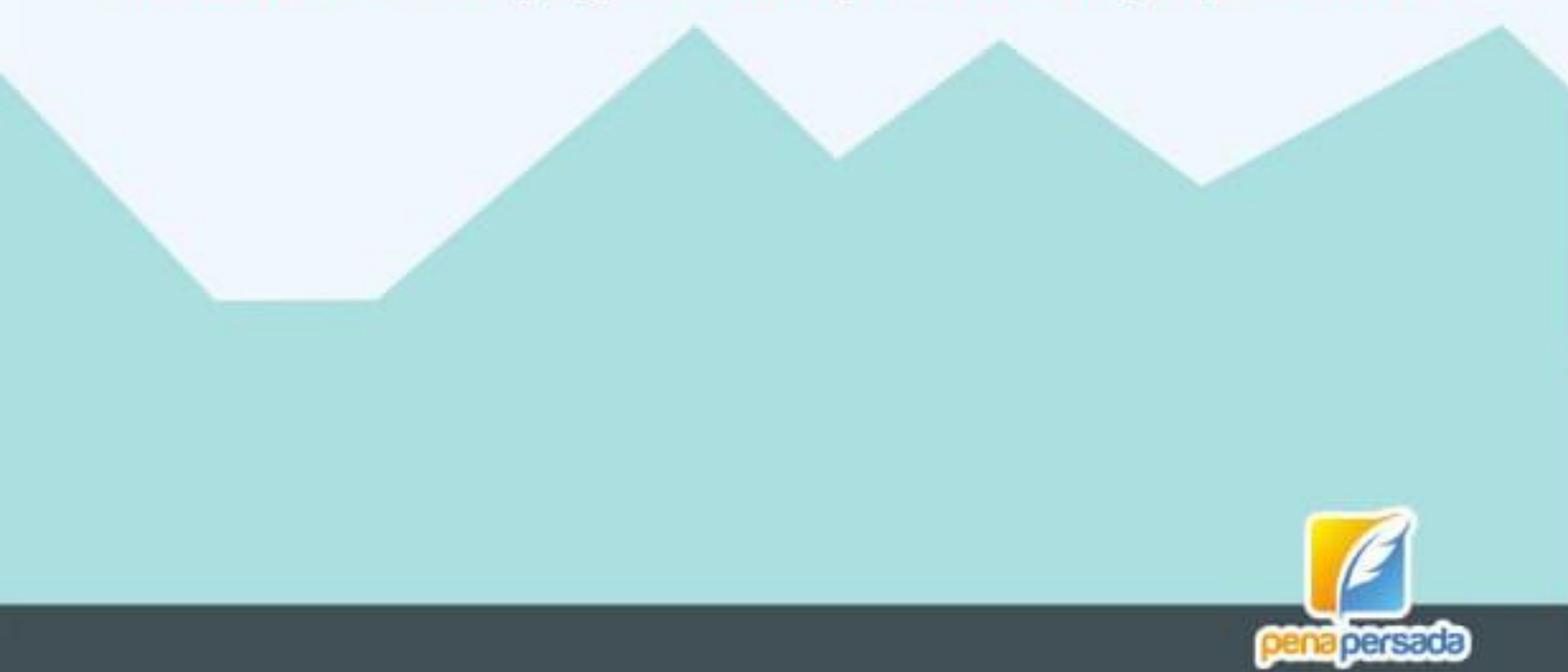

Dr. Nurminingsih, S.Sos, M.Si

\section{PENERAPAN}

PHYSICAL DISTANCING

DAN STRATEGI PEMASARAN

USAHA PEDAGANG

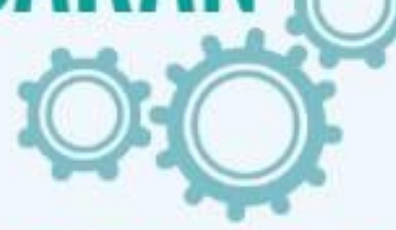

PADA MASA PANDEMI COVID-19

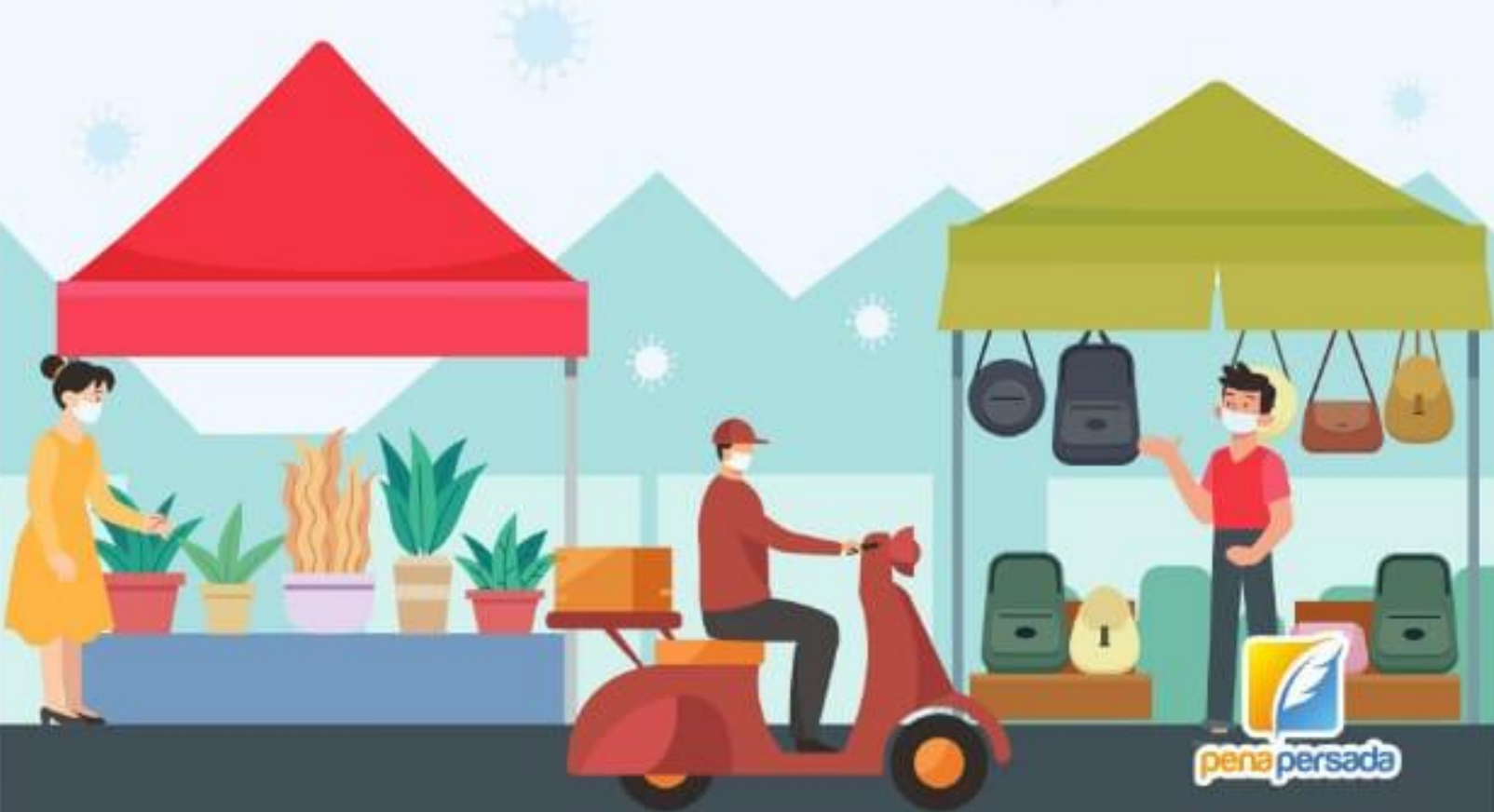




\section{PENERAPAN PHYSICAL DISTANCING \\ DAN STRATEGI PEMASARAN USAHA \\ PEDAGANG PADA MASA PANDEMI COVID-19}

Dr. Nurminingsih, S.Sos, M.Si

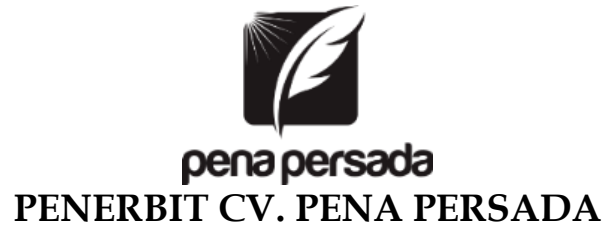




\title{
PENERAPAN PHYSICAL DISTANCING \\ DAN STRATEGI PEMASARAN USAHA \\ PEDAGANG PADA MASA PANDEMI COVID-19
}

\author{
Penulis: \\ Dr. Nurminingsih, S.Sos, M.Si
}

ISBN: 978-623-315-251-8

Editor:

Wiwit Kurniawan

Design Cover:

Retnani Nur Briliant

Layout:

Nisa Falahia

\section{Penerbit CV. Pena Persada}

Redaksi:

Jl. Gerilya No. 292 Purwokerto Selatan, Kab. Banyumas Jawa Tengah

Email: penerbit.penapersada@gmail.com Website: penapersada.com Phone: (0281) 7771388

Anggota IKAPI

All right reserved

Cetakan pertama: 2 Mei 2021

Hak Cipta dilindungi oleh undang-undang. Dilarang memperbanyak karya tulis ini dalam bentuk apapun tanpa izin penerbit 


\section{KATA PENGANTAR}

Segala puji senantiasa kita panjatkan kehadirat Allah Swt, atas segala rahmat dan karunianya, akhirnya penulis dapat menyelesaikan penyusunan buku yang berjudul "PENERAPAN PHYSICAL DISTANCING DAN STRATEGI PEMASARAN USAHA PEDAGANG PADA MASA PANDEMI COVID-19". Saya menyadari bahwa tanpa bantuan dan bimbingan dari berbagai pihak sangatlah sulit bagi saya untuk menyelesaikan karya ini. Oleh karena itu, saya mengucapkan banyak terima kasih pada semua pihak yang telah membantu penyusunan buku ini. Sehingga buku ini bisa hadir di hadapan pembaca.

Dalam buku ini membahas mengenai permasalahan faktor keberlanjutan usaha pedagang pada saat pandemi covid-19 di Lokasi Binaan Munjul. Buku ini juga mengkaji pengaruh penerapan Physical distancing dan Strategi Pemasaran terhadap Keberlanjutan Usaha Pedagang pada saat Pandemi Covid-19 di Lokasi Binaan Munjul Jakarta Timur. Pendekatan kajian ini termasuk paradigma kajian kuantitatif dengan menggunakan metode pengambilan sampel menggunakan kuesioner sebagai instrumen utama untuk mengumpulkan data. Populasi dalam kajian ini adalah pedagang di Lokasi Binaan Munjul yang tetap berjualan pada saat pandemi covid-19 dan pengambilan sampel sebanyak 122 orang sebagai sampel kajian dan menggunakan Analisis data SEM PLS-3.

Penulis menyadari bahwa buku ini masih jauh dari kesempurnaan. Oleh karena itu kritik dan saran yang membangun sangat dibutuhkan guna penyempurnaan buku ini. Akhir kata saya berharap Tuhan Yang Maha Esa berkenan membalas segala kebaikan semua pihak yang telah membantu.

Penulis 


\section{DAFTAR ISI}

KATA PENGANTAR .............................................................. ii

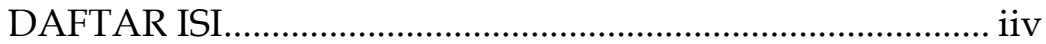

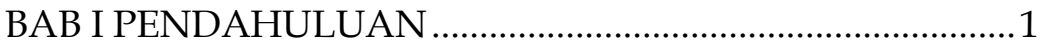

A. Dampak Covid-19 bagi Perekonomian...................... 1

B. Pendapatan UKM di Masa Pandemi .......................... 4

BAB II PHYSICAL DISTANCING ............................................

A. Gerakan Social Distancing ............................................. 8

B. Penggunaan Istilah Physical distancing di

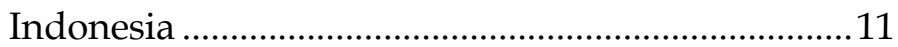

BAB III STRATEGI PEMASARAN ………….........................19

A. Definisi Strategi Pemasaran.....................................19

B. Strategi Pemasaran Online dan Offline ..................... 25

1. Strategi Pemasaran Online .....................................25

2. Strategi Pemasaran Offline ...................................26

C. Strategi Pemasaran Pedagang Pasar Tradisional ...27 BAB IV KEBERLANJUTAN USAHA ......................................38

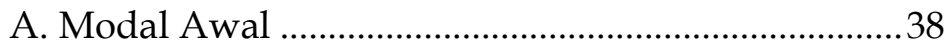

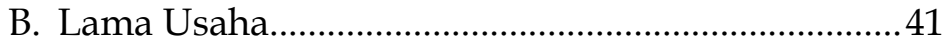

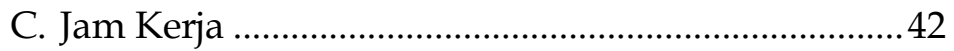

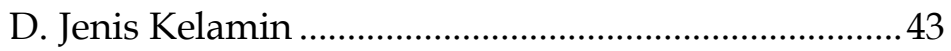

BAB V GAMBARAN UMUM LOKASI BINAAN

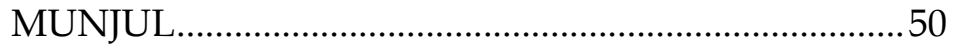

A. Profil Lokasi Binaan Munjul .......................................50

B. Struktur Organisasi Lokasi Binaan Munjul..............55

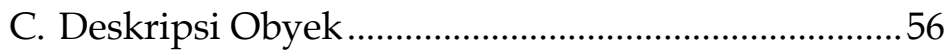

1. Karakteristik Berdasarkan Jenis Kelamin ............56

2. Karakteristik Berdasarkan Usia ..........................58

3. Karakteristik Berdasarkan Pendidikan ................59

4. Karakteristik Berdasarkan Penghasilan ...............6 61

5. Karakteristik Berdasarkan Jenis Usaha................ 62 


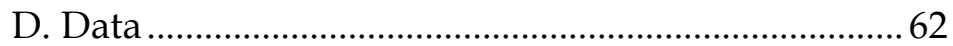

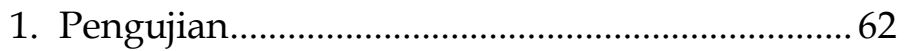

2. Koefisien Determinasi ......................................... 65

BAB VI PENERAPAN PHYSICAL DISTANCING DAN STRATEGI PEMASARAN USAHA DAGANG..........67

A. Pengaruh Physical distancing terhadap Strategi

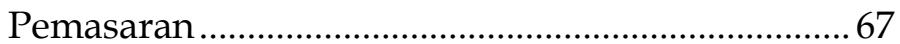

B. Pengaruh Physical distancing terhadap Keberlanjutan Usaha ................................................. 68

C. Pengaruh Strategi Pemasaran terhadap Keberlanjutan Usaha ............................................... 69

D. Physical distancing dan Strategi Pemasaran berpengaruh tidak langsung terhadap Keberlanjutan Usaha ............................................... 70

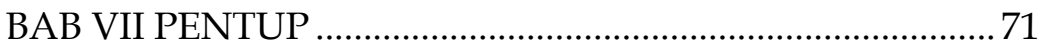

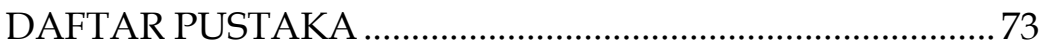

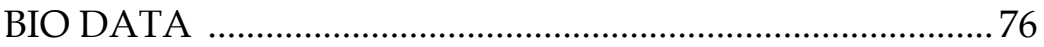




\section{PENERAPAN PHYSICAL DISTANCING \\ DAN STRATEGI PEMASARAN USAHA \\ PEDAGANG PADA MASA PANDEMI COVID-19}




\section{BAB I \\ PENDAHULUAN}

\section{A. Dampak Covid-19 bagi Perekonomian}

Perekonomian Indonesia mengalami pertumbuhan dan tercatat pada Kuartal I Tahun 2020 sebesar 4,7\% dimana secara makro ekonomi Indonesia akan terus menurun sehingga perkonomian di Indonesia dikatakan menurun drastis (www.inews.id/Kamis, 9 April 2020). Penurunan ekonomi dikarenakan adanya wabah yang terjadi di seluruh dunia termasuk Indonesia. Seperti yang penulis ketahui pada awal tahun 2020, dunia dikagetkan dengan adanya wabah pneumonia baru yang berasal dari Wuhan, Provinsi Hubei dan kemudian menyebar dengan cepat ke berbagai negara lebih dari 190 Negara. Wabah ini diberi nama Coronavirus Disease 2019 (COVID-19).

Dampak adanya wabah Covid-19 terjadi di semua sektor mulai dari sektor publik, sosial dan bisnis. Usaha Kecil Menegah (UKM) merupakan sektor bisnis yang berperan penting dalam mendorong percepatan pertumbuhan ekonomi seperti tertuang dalam Undangundang Nomor 20 Tahun 2008 pada Pasal 3 menyebutkan Usaha Mikro, Kecil, dan Menengah bertujuan menumbuhkan serta mengembangkan usahanya dalam rangka membangun perekonomian nasional berdasarkan demokrasi ekonomi yang berkeadilan. Menyikapi pandemi Covid-19 ini maka berbagai kebijakan mulai dimunculkan untuk memutus penyebaran Covid-19. Mulai dari penerapan work from home, social distancing dan physical distancing, sampai diberlakukan Pembatasan Sosial Berskala Besar (PSBB). 
Terkait Pembatasan Sosial Berskala Besar (PSBB) hampir semua daerah telah menerapkan kebijakan tersebut salah satunya Pemprov. DKI Jakarta telah mendapatkan Keputusan Menteri Kesehatan yang kemudian diturunkan kedalam Peraturan Gubernur Nomor 33 Tahun 2020 tentang Pembatasan Sosial Berskala Besar dalam Penanganan Corona Virus Disease 2019 (Covid-19) di Provinsi DKI Jakarta. Dalam peratutan tersebut dimaksud dalam rangka pembatasan aktivitas luar rumah yang dilakukan oleh setiap orang yang berdomisili dan/atau berkegiatan di Provinsi DKI Jakarta. Selama pemberlakuan PSBB, setiap orang wajib melaksanakan Perilaku Hidup Bersih dan Sehat (PHBS) dan menggunakan masker di luar rumah.

Pembatasan aktivitas luar rumah dalam pelaksanaan PSBB meliputi:

1. Pelaksanaan pembelajaran di Sekolah dan/atau institusi pendidikan lainnya;

2. Aktivitas bekerja di tempat kerja;

3. Kegiatan keagamaan di rumah ibadah;

4. Kegiatan di tempat atau fasilitas umum;

5. Kegiatan sosial dan budaya; dan

6. Pergerakan orang dan barang menggunakan moda transportasi.

Kegiatan di tempat atau fasilitas umum seperti di pasar, diberlakukan juga PSBB. Kebijakan ini tertulis pada Surat Edaran Kepala Dinas Perindustrian, Perdagangan, Koperasi, Usaha Kecil dan Menengah Prov. DKI Jakarta Nomor 79/SE/2020 tentang Himbauan Teknis Antisipasi dan Pencegahan Penyebaran Corona Virus Disease (Covid-19) pada Area Lokasi Binaan dan 
Lokasi Sementara Kuliner di Wilayah Provinsi DKI Jakarta, bahwa setiap pedagang di Lokasi Binaan dan Lokasi Sementara Kuliner harus mengambil langkahlangkah sebagai berikut :

1. Mengutamakan pelayanan take away atau online dan meminimalisir pelayanan makan ditempat;

2. Apabila tetap harus melayani makan di tempat wajib menata tempat makan agar antar konsumen terdapat jarak aman minimal 1 (satu) meter antar orang;

3. Menyediakan tempat cuci tangan disertai dengan sabun;

4. Menerapkan etika bersin/batuk (menutup mulut/ hidung saat bersin/batuk dengan menggunakan tissue) kemudian buang tissue yang sudah digunakan ke tempat sampah;

5. Menerapkan kebiasaan mencuci tangan terutama setelah bersin atau batuk, sebelum dan sesudah menyiapkan makanan, sebelum dan sesudah makan, serta setalah menggunakan toilet dan merawat bianatang.

6. Selalu menjaga kebersihan peralatan dan perlengkapan yang digunakan serta lokasi usaha;

Kebijakan tersebut sedikit banyak berpengaruh pada kegiatan bisnis di pasar Lokasi Binaan Munjul dimana terjadi adanya penurunan jumlah pelanggan dan penuruanan omset pada beberapa pedagang. Penerapan jaga jarak atau physical distancing di pasar menjadi perhatian khusus karena pasar merupakan interaksi antara pedagang dan penjual yang memungkinkan terjadinya kontak fisik, hal tersebut karena ruang pasar yang sempit, penuh dengan pedagang dan barang yang 
diperdagangankan. Oleh karena itu, penerapan physical distancing menjadi fokus utama penulis dalam kajian ini.

\section{B. Pendapatan UKM di Masa Pandemi}

UKM mengalami dampak yang paling besar dan berat sebab hampir seluruh masyarakat menopang perekonomian keluarga mereka bersumber dari usaha berdagang di Lokasi Binaan (Lokbin) Munjul. Lokasi Binaan (Lokbin Munjul) ini merupakan fasilitas yang disediakan oleh Suku Dinas PPKUKM yang dituangkan dalam Keputusan Kepala Sudin PPKUKM Nomor 10/2017 tentang Penepatan Lokasi Binaan Mikro/ Pedagang Kaki Lima di Kota Administrasi Jakarta Timur.

Menurut data dari Kasatpel Sudin PPKUKM Kecamatan Cipayung Jakarta Timur, terdapat 16 jenis usaha dan 272 pedagang, semua pedagang terdaftar pada simpad.jakarta.go.id serta pedagang berkewajiban membayar retribusi setiap hari sebesar Rp. 4.000,- yang akan di auto debet langsung oleh Bank DKI. Namun, sampai saat ini belum ada kebijakan terkait pengurangan biaya retribusi berdasarkan hasil wawancara penulis dengan Pedagang sedangkan penghasilan/omset pedagang karena pandemi Covid-19 tidak normal bahkan cenderung berkurang.

Berdasarkan Peraturan Gubernur Nomor 33 Tahun 2020 tentang Pelaksanaan Pembatasan Sosial Berskala Besar dalam Penanganan Corona Virus Disease 2019 (Covid-19) di Provinsi DKI Jakarta pada Pasal 10, bahwa terdapat pelaku usaha yang diperbolehkan tetap beraktivitas yaitu bergerak pada sektor : 
1. Kesehatan;

2. Bahan pangan/makanan/minuman ;

3. Energi ;

4. Komunikasi dan teknologi informasi ;

5. Keuangan;

6. Logistik ;

7. Perhotelan;

8. Konstruksi ;

9. Industri strategis ;

10.Pelayanan dasar, utilitas publik ;

11.Kebutuhan sehari-hari

Berdasarkan pelaku usaha di atas, maka usaha yang bergerak dapat dibagi menjadi 2 kategori yaitu Pangan dan Non Pangan pada tabel 1.1

Tabel 1.1

Kategori Pedagang

\begin{tabular}{|c|l|c|}
\hline No & \multicolumn{1}{|c|}{ Kategori } & Jumlah \\
\hline 1 & Pangan & 201 \\
\hline 2 & Non Pangan & 71 \\
\hline & Total Pedagang & 272 \\
\hline
\end{tabular}

Sumber : Kasatpel PPKUKM Kecamatan Cipayung, 2020

Berdasarkan Tabel 1.1 terlihat bahwa jumlah pedagang Pangan sebanyak 201 pedagang lebih banyak dibandingkan dengan Non Pangan sebanyak 71, hal ini berarti bahwa keberadaan pedagang pangan akan sangat berdampak dengan adanya kebijakan PSBB dan dilihat dari kondisi di lapangan yakni di Lokasi Binaan Munjul masih banyak pedagang dan pembeli yang belum menerapkan jaga jarak (physical distancing) yang dilakukan oleh pembeli pada saat membeli produk oleh pedagang dan ada juga pembeli dan pedagang yang tidak 
memakai masker yang seharusnya mengikuti Seruan Gubernur Nomor 9 Tahun 2020. Hal ini terjadi karena adanya kurang kesadaran dari para pedagang dan pembeli sehingga kebijakan yang ada menjadi kurang bermakna dan efektif yang akibatnya dapat menambah jumlah penderita yang akan terpapar Covid-19.

Akibat dari kondisi tersebut maka metode pemasaran pada saat pandemi Covid-19 diimbangi dengan berjualan secara online, sebab untuk melaksanakan pemasaran online secara keseluruhan tidak memungkinkan karena beberapa faktor. Faktor kebiasaan seperti pada kondisi normal dimana penjualan dilaksanakan secara konvensional dengan pertemuan langsung anatara penjual dan pembeli sebagaimana layaknya pasar tradisional di seluruh Indonesia.

Pada saat pandemik ini ketika transaksi jual beli di pasar dilaksanakan, maka peraturan mengharuskan agar pedagang dan pembeli menjaga jarak dengan memakai tata cara yang berlaku. Selain itu transaksi secara langsung dibatasi dengan jam operasional yang mengharuskan pedagang dan pembeli melakukan transaksi di jam yang telah ditentukan yaitu pukul 05.00 s.d 12.00 setelah jam tersebut Lokbin harus steril tidak boleh ada kegiatan transaksi yang dilakukan di Lokbin. Setelelah jam operasional ditutup permintaan akan produk tetap banyak, sehingga startegi secara online terpaksa dilakukan agar pendapatan tetap masuk meskipun para pedagang merasa tidak nyaman dan merasa kesulitan secara teknis dimana barang dagangan yang mereka jual harus dibawa pulang ke rumah dank e sokan harinya dibawa kembali ke pasar, meskipun barang dagangan belum tentu habis dan laku. 
Menurut Kasatpel PPKUKM Kecamatan Cipayung, jumlah pedagang sebelum dan sesudah adanya pandemi Covid-19 mengalami penurunan. Sebelum pandemi ada sekitar 272 pedagang dan ketika mewabah pandemi menjadi 209 pedagang, artinya sekitar 63 pedagang tidak berjualan lagi karena merugi atau tutup. 


\section{BAB II. \\ PHYSICAL DISTANCING}

\section{A. Gerakan Social Distancing}

Pada awal tahun 2020 ini dunia dikejutkan dengan wabah virus corona (Covid-19) yang menginfeksi hampir seluruh negara di dunia. WHO Semenjak Januari 2020 telah menyatakan dunia masuk kedalam darurat global terkait virus ini (Sebayang, 2020). Negara Indonesia melalui Pemerintah telah mengeluarkan status darurat bencana terhitung mulai tanggal 29 Februari 2020 hingga 29 Mei 2020 terkait pandemi virus ini dengan jumlah waktu 91 hari. Langkah-langkah telah dilakukan oleh pemerintah untuk dapat menyelesaikan kasus luar biasa ini, salah satunya adalah dengan mensosialisasikan gerakan Social Distancing. Konsep ini menjelaskan bahwa untuk dapat mengurangi bahkan memutus mata rantai infeksi Covid-19, seseorang harus menjaga jarak aman dengan manusia lainnya minimal 2 meter, dan tidak melakukan kontak langsung dengan orang lain, menghindari pertemuan massal.

Membatasi kontak dengan orang lain menjadi cara terbaik untuk mengurangi penyebaran penyakit coronavirus 2019 (Covid-19). Organisasi Kesehatan Dunia (WHO) menggunakan beberapa istilah yakni social distancing, physical distancing, karantina dan isolasi. Namun ada juga PSBB (Pembatasan Sosial Berskala Besar). Organisasi Kesehatan Dunia (WHO) menyebut jaga jarak dengan istilah social distancing. Pada perkembangan berikutnya, istilah social distancing diubah dengan istilah physical distancing. 
Social distancing mengacu pada penciptaan ruang fisik antara satu dengan yang lain dan menghindari pertemuan besar. Menurut Aldrich (2020), penjelasan itu menyesatkan dan penggunaannya yang luas dapat menjadi kontraproduktif. Dengan makna seperti di atas, lebih tepat digunakan istilah physical distancing. Upaya yang dilakukan untuk memperlambat penyebaran virus corona harus mendorong penguatan ikatan sosial dengan tetap menjaga jarak fisik.

Hal yang sama dilakukan di Indonesia dan menurut Kepala Badan Nasional Penanggulangan Bencana (BNPB), Doni Monardo (2020) mengemukakan bahwa jaga jarak ini bukan hanya berlaku di tempat umum, tetapi juga berlaku di seluruh rumah tangga di setiap keluarga. Penerapan Pembatasan Sosial Berskala Besar (PSBB) di Jakarta telah berlaku sejak 10 April 2020 melalui Peraturan Gubernur (Pergub) Nomor 33 Tahun 2020. Warga Jakarta diimbau beraktivitas di rumah. Pada situasi pandemi Covid-19 ini masyarakat harus berada di sekitar orang, jaga jarak dengan orang lain sekitar 6 kaki (2 meter).

Menurut Johns Hopkins Medicine (2020) yang harus dilakukan ketika physical distancing diantaranya bekerja dari rumah alih-alih di kantor, menutup sekolah atau beralih ke kelas online, bertemu orang lain dengan telepon atau video call alih-alih secara langsung dan membatalkan atau menunda konferensi dan rapat besar. Adapun perbedaan Social Distancing, Physical distancing, Karantina, Isolasi dan Pembatasan Sosial Berskala Besar (PSBB) adalah sebagai berikut : 


\section{Social Distancing}

Adalah menjaga jarak sosial yang berarti menjaga jarak antara diri sendiri dan orang lain di luar rumah sekitar dua meter dan menjauhi tempat ramai, pertemuan massal, hingga berkumpul dengan kelompok.

2. Physical distancing

Adalah bagian dari Social Distancing untuk menghindari penyebaran virus corona yang lebih luas yang dilakukan dengan menjaga jarak fisik namun orang-orang tetap bisa berinteraksi secara sosial sesuai jarak yang dianjurkan.

3. Karantina

Adalah cara yang digunakan untuk memisahkan orang yang mungkin sudah terpapar virus corona sehingga mereka harus terpisah dari orang lain dan membatasi pergerakan di luar rumah.

4. Isolasi

Adalah cara yang digunakan untuk memisahkan orang sakit dari orang sehat. Orang yang berada dalam isolasi harus tinggal di rumah, harus memisahkan diri dari orang lain dengan tetap di kamar atau ruang "sakit" tertentu dan menggunakan kamar mandi yang berbeda (jika dimungkinkan).

5. Pembatasan Sosial Berskala Besar (PSBB)

Adalah pembatasan sosial berskala besar dalam rangka percepatan penanganan virus corona. Salah satu lingkup PSBB adalah meliburkan sekolah dan tempat kerja, pembatasan kegiatan keagamaan, pembatasan kegiatan di tempat umum, pembatasan transportasi, hingga pembatasan kegiatan sosial dan budaya. Jika dilanggar maka akan dikenakan biaya sampai dengan Rp 100 juta atau setahun penjara. 
Perkembangan konsep atas substansi jaga jarak dari social distancing ke physical distancing dapat ditinjau dari kepentingan keilmuan dan pragmatisme. Dari sisi keilmuan sosial, istilah social distancing menunjukkan ketepatannya. Istilah itu menunjuk kepada pentingnya menjaga jarak dari kerumunan. Sebab, kata "sosial" berarti gabungan dari individu-individu. Lebih dari itu, kata tersebut merujuk pada adanya hubungan antara individu satu dan lainnya dalam gugus atau kelompok tertentu. Maka, ketika ada kepentingan untuk memutus mata rantai persebaran dan atau penularan virus corona di tengah masyarakat, istilah social distancing bisa dan absah digunakan.

Namun, bagi masyarakat dengan kultur yang mengandalkan kerumunan dalam relasi sosialnya, penggunaan istilah social distancing bisa menimbulkan salah arti atau minimal bias makna. Bentuknya adalah kesalahpahaman yang dapat berarti bahwa warga dilarang menjaga hubungan baik dengan sesamanya di saat dan atau selama persebaran virus corona yang tak terkendali. Jika salah arti atau bias makna itu muncul, kampanye pemutusan mata rantai persebaran virus corona melalui praktik jaga jarak antara satu individu dan lainnya bisa tidak efektif. Akibatnya kampanye tersebut bisa disalahpahami secara kontraproduktif oleh masyarakat. Bahwa mereka diajak bersikap dan berperilaku antisosial dan atau tak hirau dengan nasib sesama.

\section{B. Penggunaan Istilah Physical distancing di Indonesia}

Pemerintah Indonesia tampak cenderung lebih nyaman dengan penggunaan istilah physical distancing. Di negara kita yang paling pas adalah physical distancing, 
menjaga jarak aman, seperti yang dikemukakan oleh Presiden Jokowi di Istana Merdeka, Jakarta pada tanggal 24 Maret 2020 lewat rapat terbatas video conference dengan para gubernur se-Indonesia. Presiden Jokowi mengambil kebijakan untuk lebih menggunakan istilah physical distancing daripada social distancing, dengan berlandaskan dari perspektif dan kepentingan pragmatis, sebab lebih konkret, terukur, dan langsung mengena pada keseharian masyarakat. Apalagi, dalam basis kognitif kebahasaan Indonesia, kata "fisik" menunjuk kepada tubuh secara material.

Pergerakan dari social distancing ke physical distancing bukan soal benar-salah karena keduanya benar. Isu sentral dari pergeseran penggunaan istilah bahasa dimaksud lebih karena faktor pragmatisme untuk suksesnya kampanye tanggap virus corona. Physical distancing menjelaskan bahwa untuk dapat mengurangi bahkan memutus mata rantai infeksi Covid-19 seseorang harus menjaga jarak aman dengan manusia lainnya minimal 2 (dua) meter, dan tidak melakukan kontak langsung dengan orang lain, menghindari pertemuan massal (CNN Indonesia, 2020).

Kebijakan social distancing atau physical distancing sebelumnya hanyalah berupa imbauan, adanya PSBB ini diklaim akan bersifat mengikat, sehingga siapa pun yang melanggar dapat dikenai sanksi. Namun disisi lain kebijakan PSBB memiliki batasan waktu sehingga apabila kebijakan PSBB diakhiri sanksi tidak dapat diterapkan, lain halnya dengan penerapan physical distancing yang dapat diberlakukan secara terus menerus dalam jangka waktu panjang karena penerapannya tidak dibatasi waktu. 
Physical distancing jadi kunci suskses pelaksanaan pengendalian penularan Covid-19. Saat ini dirasa perlu untuk diperkuat, karena dalam beberapa hari terakhir masih ditemukan ketidakefektifan pelaksanaan ini akibat belum disiplin masyarakat. Saat melaksanakan physical distancing terdapat beberapa hal yang sebaiknya dilakukan yakni :

1. Menaati rekomendasi kebersihan 13ook13g seperti mencuci tangan setelah menyentuh benda-benda yang lazim digunakan orang sakit,

2. Mencuci tangan yang baik setidaknya menggosok bagian-bagian tangan selama 20 detik menggunakan air dan sabun,

3. Hindari menyentuh wajah, hidung, mulut, serta jangan menggosok kelopak mata,

4. Praktikkan etika batuk dan bersin. Buang dengan baik barang-barang yang bersentuhan dengan mulut, misalnya tisu, peralatan makan 13ook13g13, hingga sikat gigi bekas,

5. Hindari berinteraksi dengan orang yang menunjukkan tanda-tanda mengalami sakit,

6. Jika bekerja dalam jarak dekat dengan rekan kerja, pastikan untuk menjaga jarak hingga 2 (dua) meter jika tidak memungkinkan, setidaknya hingga 1 (satu) meter paling dekat;

7. Hindari juga untuk berkumpul di area 13ook13g, seperti ruang teater, atau pertandingan olahraga;

8. Jika memungkinkan, lakukan aktivitas fisik dan berolahraga setiap harinya untuk menjaga kebugaran tubuh; 